084

Received: July 7, 2009

Accepted: November 30, 2009

\title{
ECONOMICAL BENEFIT FROM OSTRICH (Struthio camelus L.) BREEDING AND PRIMARY PROCESSING
}

\author{
Aco Kuzelov, Momčula Jordanoski, Živko Gacovski, Dijana Trajčova \\ University "Goce Delčev", Faculty of Agriculture, \\ Bul. Krste Misirkov bb, Štip, Republic of Macedonia \\ aco.kuzelov@ugd.edu.mk
}

\begin{abstract}
This work includes the economic benefit of ostrich rising and methods of primary analyses, ostrich transport to the slaughter house resting before primary treatment, stunning with blood, plucking the plumage, cutting the legs and the head, exenteration (removal of internal organs), washing, filtration and cooling.
\end{abstract}

Key words: ostrich; economic benefit; primary analyses

\section{СТОПАНСКА КОРИСТ ОД ОДГЛЕДУВАЊЕТО НА НОЕВИ (Struthio camelus L.) И ПОСТАПКИ ПРИ НИВНАТА ПРИМАРНА ОБРАБОТКА}

\begin{abstract}
Во трудот се разгледани стопанската корист од одгледувањето на ноевите (Struthio camelus) и постапките пред и за време на нивната примарна обработка, како и постапката при транспортот на ноевите до кланицата, одморањето пред примарната обработка, терањето на ноевите од депото во кланицата, зашеметувањето, искрвавувањето, кубењето на перјата, отстранувањето на нозете и главата, егзентерацијата, миењето, цедењето и ладењето.
\end{abstract}

Клучни зборови: ној; стопанска корист; примарна обработка

\section{INTRODUCTION}

Ostrich cultivation in farm conditions is very popular and profitable these days. Ostrich (Struthio camelus L.) is the biggest flyless bird in the world, with 2.7 meters height and 100-160 kg weight (http://hr.wikipedia.org/wiki/Noj).

The economic benefit of breeding ostriches is big, considering the use of almost all products such as feathers, leather, meat and eggs, oil.

Big demand for feathers from ostriches was the occasion for plant of ostriches in South Africa in 1860 . Breeding ostriches spread worldwide by the end of the last century (Australia, Argentina, Botswana, Brazil, France, Israel, Namibia, Spain, England and USA).

This paper presents the estimation of economical benefit by ostrich breeding and primary process. Ostrich primary processing consists of ostrich transportation, resting before slaughtering, transportation to the slaughterhouse, slaughtering, bleeding out, feather pluck, leg and head removing, washing, leaching and cooling (Драгоев, 2004).

Ostrich breeding in Macedonia is at the very beginning. The situation in ostrich breeding is not quite good, firstly because of lack of knowledge about the chemical composition of ostrich meat and secondly because of organization problems in farming, slaughtering and exporting.

The economical benefit and primary processing of ostriches are given in this paper.

\section{ECONOMICAL BENEFIT FROM OSTRICH}

\section{Leather}

Soft to the touch, the leather of ostrich is both flexible and durable, making it an ideal working material for the manufacture of most leather goods 
and certainly luxury leather items. Because of these characteristics, ostrich leather is one of the chosen materials for fashion in boots making, handbags, wallets, belts and clothing. Leading fashion houses, such as Hermes, Louis Viton, Prada, Gucci and many others choose ostrich leather to exhibit its beauty and its high class status. Full of natural oils, ostrich leather resists drying and cracking and no other leather in the world can compete with it. This makes it one of the most expensive leathers in the world today with a range of $80-120 \$$ per $\mathrm{m}^{2}$ in USA.

\section{Meat}

Ostriches produce red meat that is very similar in taste and texture to beef. It is low in fat, cholesterol and an excellent source of protein and iron. The average meat yield of one ostrich bird is about $20-30 \mathrm{~kg}$ of deboned meat. Statistics show that current ostrich meat production is not enough to meet the increasing demand. In USA prime ostrich meat cuts costs aproximately $8-10 \$$. One day chick costs $50-80 \$, 30$ to $50 \mathrm{~kg}$ chicks costs $130-200 \$$, finished slaugtered birds $280-470 \$$ (http://www4.agr.gc.ca/AAFC-AAC/).

According to Petar Jovanov, the president of the Macedonian Ostrich Society, $1 \mathrm{~kg}$ ostrich meat in Macedonia is about $400-450$ den, one month old ostrich chick in Macedonia is about $80-100$ euros.

\section{Eggs}

One hen lays on average 60 eggs per year, each weighing about $1,5 \mathrm{~kg}$. Empty egg - shells are most valuable than complete eggs. These are decorated and very popular as souvenirs. One hatching egg costs about $20-50$ \$ in USA (http://www4.agr.gc.ca/AAFC-AAC/).

\section{Feathers}

Ostrich feathers are equally long on both sides of the central shaft. Ostrich feathers are used for cleaning fine machinery and equipment as well as for decorations and fashion industry (Joy, 2005).

\section{OSTRICH PRIMARY PROCESS}

Ostrich primary processing is made according to the requirement of sanitary-hygienic and veterinary requirements and according to the Regulation for protection and well condition of animal, No.
113 from 2007, and Regulation for special needs for animal products, No. 115 from 2008. These are technological stages in ostrich processing:

1. Live ostriches;

2. Lading in the transport vehicle - trucks;

3. Transport;

4. Unlading in the slaughter house;

5. Resting for stress releasing;

6. Anesthesia;

7. Slaughter;

8. Blooding;

9. Feathers removing;

10. Egzenteration;

11. Carcass washing;

12. Meat cooling.

\section{Lading, transport and anlading}

Transport of ostriches from the farm to the slaughterhouse is with the special vehicle. It is very important to minimize the noise during the transport, because it can be very stressful for the birds. Because of that, during the transport they have on their head a bag full of selen solution. This solution causes relax atmosphere for the birds and releases them from the stress during the transport. Every transport of ostriches must be followed by the workers who are walking by their side and on the back. The path should be limited with a high wall so the ostriches will go one by one and minimize the chance for their injury.

\section{Resting}

After entering the ostriches in the slaughter house, each of them must be specifically placed in a separate cage to rest and be quiet. Those places are separate from the place for slaughter, so they will stay here until they stabilize their mental condition away from noise and stress.

\section{Fuddle}

Fuddles for ostriches is made in shambles, with electricity. Using electricity before the slaughter enables the achievement of human procedure to remove the stress in the animals. In that way, panic is not created in the slaughterhouse, and the creation of violations of ostriches for slaughter is prevented.

According to some authors, only fuddle ostrich need electricity from $50 \mathrm{~Hz}$ during 4 seconds. 
Electrodes for production electricity are high level quality ones, which are follow international standards and are very easy for manipulation. They put on head to the bottom of the key. This method prevents damaging corneal eye, which is used for medical purposes. Electroshock is performed using the standard, trusted apparatus with simple handling.

\section{Bleeding}

The bleeding of ostriches goes after slaughtering the ostrich. Bleeding must be made in full, to enable observation ostrich meat quality for the consumer goods. Bleeding is completely possible in this way so that the two incision knifes are used, the first is in the chest, and the other on the neck of the ostrich.

\section{Removal of feathers}

Removal of feathers from the ostrich body is made on dry, without any water. Removal of feathers must be done completely and professionally, because of inhibition skin injuries. The next phase is the removal of skin and cutting the meat on pieces.

\section{Exenteration}

Exenterating ostriches of internal organs is done in the hammock position of troops. After slaughtering and removing the skin, the incision in the keel trunk is made by the electric saw. In the last phase of the approach of internal organs, washing the troops and storage of the meat in the refrigerator follow.

\section{Washing}

After removing the inside organs, the carcass is washed with water, so there will be no more any dirty pieces or blood.

The next stage is putting the meat into the refrigerators during the transport in the trade markets.

\section{Measurements of weight}

With the measurement the randman of the carcass and their weight are defined.

\section{Cooling}

Transport of fresh ostriches meat is with special truck with cooler, and the inside temperature is $+4{ }^{\circ} \mathrm{C}$.
The slaughtering of ostriches is well established in South Africa, Israel, Australia and Zimbabwe. Quite different methods are used in each country, but the most regular are the next:

Ostriches are offloaded from a truck into a walled run. Rubber mats are provided to help reduce injury through slipping. Green padding is placed on all walls of the loading ramp, run and holding pens. The walls should be high enough to prevent the ostrich from seeing over to minimize panic. The bird needs adequate feeding, watering and resting for 24 hours. The pens must be well padded and the floors well drained. The anesthesia is after the weighing with 80 volts to the head. Bleeding is done by cutting the throat near the head. Plucking off feathers is done manually. The carcass is then skinned and the skin is wet - salted. The feet are removed by a mechanical cutter. The exenteration is divided into clean offal (lungs, gizzard, liver, kidneys and heart) and dirty offal (trachea, viscera, gonads and abdominal fat). Within 30 minutes of bleeding, the thighs and legs are removed and cooled at $0-4{ }^{\circ} \mathrm{C}$ for 24 hours (Cooper, 2000).

\section{CONCLUSIONS}

The raw materials of the ostrich industry come mainly from abattoir. That's why the slaughtering process is very important.

The economical benefits of ostriches are big because of the number of products from one ostrich (meat, feather, skin, oil). The prices of these ostrich products are good enough. The market for ostrich meat is very big and more and more meat is needed every day, especially in the Middle East.

Ostrich business is very profitable, but also needs some regulations to work on it. For example in Macedonia there is no slaughterhouse that can slaughter and debone ostrich carcass. Ži-Va can slaughter only. There is no regulative for ostrich slaughtering. There is no export number, to export the meat in Europe or other countries. Macedonian ostrich farmers must export live weight ostriches and the price is 3 euros per kilo that is very little compared with $8-10$ euro for one kilo ostrich meat.

This perspective agro business can bring good investments and work places in our country, that's why it is good to work a little on this problem. 


\section{REFERENCES}

[1] Cooper R. G. (2000): Meat from the ostrich - Slaughtering, meat inspection and health risks, Fleish Wirtschaft International.

[2] Carbajo, E. (2006): Ostrich production to mature, World Poultry, Vol. 22, No. 8.

[3] Драгоев, С. Г., (2004). Развитие на технологията в месната и рибната промишленост. Академично издателство на УХТ, Пловдив, 249-256.
[4] Joy Antoinette (2005): Ostrich farming then and now, World Poultry. Vol. 21, No 3.

[5] Shane, S. (2003): World ostrich industry is declining despite potential, World Poultry, Vol. 19, No. 9.

[6] http://www4.agr.gc.ca/AAFC-AAC/

[7] http://hr.wikipedia.org/wiki/Noj. 